\title{
Stratigraphy and chronology of the Stent tephra, a c. 4000 year old distal silicic tephra from Taupo Volcanic Centre, New Zealand
}

\author{
BRENT ALLOWAY \\ Department of Geology \\ University of Auckland, Tamaki Campus \\ Private Bag 92019 , \\ Auckland, New Zealand \\ DAVID J. LOWE \\ Department of Earth Sciences and \\ Geochronology Research Unit \\ University of Waikato \\ Private Bag 3105 \\ Hamilton, New Zealand

\section{R. P. K. CHAN} \\ Department of Mathematics and Statistics \\ University of Auckland, Tamaki Campus \\ Private Bag 92019 \\ Auckland, New Zealand
}

\section{DENNIS EDEN}

Landcare Research N.Z. Ltd.

Private Bag 11052

Palmerston North, New Zealand

\section{PAUL FROGGATT \\ Research School of Earth Sciences Victoria University of Wellington P.O. Box 600 \\ Wellington, New Zealand}

\begin{abstract}
Tephrostratigraphic and chronologic studies in two areas of the North Island have identified a previously unrecorded, thin, distal silicic tephra derived from the Taupo Volcanic Centre. In Taranaki, three radiocarbon ages of the uncorrelated tephra are consistent with the independent radiocarbon chronology obtained from enveloping Egmontsourced tephras. In western Bay of Plenty, where the uncorrelated tephra is also directly dated, it is overlain by Whakaipo Tephra (c. $2.7 \mathrm{ka}$ ) and underlain by Hinemaiaia Tephra (c. $4.5 \mathrm{ka}$ ). From these sites in Taranaki and western Bay of Plenty, seven radiocarbon dates obtained on the uncorrelated silicic tephra yield an error-weighted mean age of $3970 \pm 31$ conventional radiocarbon years B.P. The ages on the uncorrelated tephra (informally referred to as Stent tephra) from both areas are statistically identical but significantly different from those on both Waimihia and Hinemaiaia Tephras.
\end{abstract}

G93028

Received 5 July 1993; accepted 14 September 1993
The occurrence of Stent tephra in Taranaki, c. $160 \mathrm{~km}$ upwind from the postulated source area, and in western Bay of Plenty, suggests that it represents the product of a moderately large plinian eruption. Until recently, its validity as a discrete eruptive event had been problematical, because a near-source equivalent deposit between Waimihia and Hinemaiaia Tephras was not recognised in the Taupo area. However, a revised stratigraphy proposed by C. J. N. Wilson in 1993 for eastern sectors of the Taupo area shows that multiple tephra layers were erupted from Taupo volcano between c. 3.9 and $5.2 \mathrm{ka}$. Of these newly recognised layers, unit- $Q$ - the product of a moderately large eruption $(\geq 0.15$ $\mathrm{km}^{3}$ ) at c. $4.0 \mathrm{ka}$-is tentatively correlated with Stent tephra. Other eruptive units recognised by Wilson are either too old or too small in volume to be considered as likely correlatives.

Keywords stratigraphy; tephra; Holocene; Taupo volcano; distal; Stent tephra; ${ }^{14} \mathrm{C}$ dating; unit- $Q$

\section{INTRODUCTION}

The stratigraphy, distribution, chronology, and eruptive processes of silicic tephras erupted from Taupo Volcanic Centre over the last 22 ka have been extensively studied (e.g., Baumgart 1954; Baumgart \& Healy 1956; Healy 1964; Vucetich \& Pullar 1969, 1973; Vucetich \& Howorth 1976; Froggatt 1981a-d, 1982; Walker 1980, 1981a, b; Wilson et al. 1980, 1984, 1986). Many eruptives were also identified and correlated from distal sequences of organic-rich deposits, which provided not only an opportunity to improve the chronology for many of the tephras through radiocarbon dating of the intervening organic sediments, but also a clearer record of the stratigraphic relationships of interbedded tephras derived from different volcanic centres (e.g., Topping \& Kohn 1973; Lowe et al. 1980; Hogg \& McCraw 1983; Lowe \& Hogg 1986; Lowe 1986, 1988a, b; Froggatt \& Lowe 1990; Froggatt \& Rogers 1990; Pillans \& Wright 1992; Eden et al. 1993). It was therefore considered that the Holocene eruptive record from Taupo Volcanic Centre was completely known, at least for the major eruptives. However, recent studies of distal tephra sequences contained within peat and estuarine sediments from two widely separated North Island localities suggested the possibility of a widespread and previously unrecognised Holocene eruptive event from the Taupo Volcanic Centre. This eruptive unit, aged c. $4.0 \mathrm{ka}$, is the main subject of this paper.

\section{STRATIGRAPHY OF THE PREVIOUSLY UNCORRELATED DISTAL TEPHRA}

Previous studies in North Taranaki have reported the occurrence of a silicic ash layer intercalated with late Holocene distal andesitic tephra from Egmont volcano (Neall 
\& Alloway 1986; Alloway 1989). On the basis of its ferromagnesian mineralogy and glass composition, this ash layer was identified as an eruptive unit derived from the Taupo Volcanic Centre. Three radiocarbon dates were obtained for the tephra, which, at the time, suggested tentative correlation with Waimihia Tephra-as defined by Vucetich \& Pullar (1973) (Alloway 1989; Alloway et al. 1992). However, it was noted that these dates were all about 500 years older than those ages obtained for Waimihia Tephra from elsewhere in the North Island, but they were consistent in age with the independent radiocarbon chronology obtained from the enveloping Egmont-sourced tephra layers. Cores containing airfall tephras interbedded with organic sediments have since been investigated at Papamoa Bog in the western Bay of Plenty (Fig. 1). In cores from this locality, which has a more comprehensive silicic tephrostratigraphy than in Taranaki, a silicic tephra has been identified with an age that closely corresponds with those obtained from Taranaki. From these widely dispersed North Island localities, the nature, stratigraphic position, and age of this previously uncorrelated silicic tephra, and those tephra layers immediately adjacent to it, are specifically examined to establish its validity as a widespread Holocene eruptive from the Taupo Volcanic Centre.

\section{Tephrostratigraphy}

\section{Taranaki}

The uncorrelated silicic tephra was first recognised by Wellman (1962) in Holocene coastal sections of Taranaki as "a laminated silt-grade putty coloured ash" and named as the middle member of Stent Ash. The upper and lower members of Stent Ash were subsequently identified (Neall \& Alloway 1986; Alloway 1989) as distal equivalents of Inglewood and Korito Tephras, respectively-both locally sourced andesitic units from Egmont volcano (Neall 1972; Alloway 1989). The silicic tephra (hereafter informally named Stent tephra) was subsequently identified in five further sections in central Taranaki (Fig. 1A) where it was easily distinguished from adjacent andesitic tephra on the basis of its conspicuous paler colour and consistent siltgrade glassy texture. Where interbedded in peat or coastal sands, Stent tephra forms a discontinuous, white to yellow (10YR 8/2-7/6), well sorted, glassy, very fine ash. In estuarine sediment, it is usually continuous and uniformly thick $(20 \mathrm{~mm})$ with a characteristic pinkish (5YR 7/3) colour. Stent tephra may also match a minor peak of dispersed silicic glass recorded by Stewart et al. (1977) within the upper profile of a representative Andisol from South Taranaki.

Three radiocarbon dates for Stent tephra have so far been determined from Taranaki (Fig. 2). In an open drain at Kaimata (section T2), a radiocarbon date (NZ6702A) of $3580 \pm 80$ yr B.P. was obtained from a bulk peat sample between the discontinuously exposed Stent tephra and underlying Korito Tephra. Two further radiocarbon dates (Wk-1259A and Wk-1032A) of $3940 \pm 70$ and $3870 \pm 110$ yr B.P. were obtained from peat immediately beneath Stent tephra near Mangamingi and Onaero, respectively (sections $\mathrm{T} 1$ and T3). At the Onaero section (T3), the enveloping andesitic tephras were also radiocarbon dated in sequence along with Stent tephra (Fig. 2). The resultant dates for these andesitic tephra layers are: Inglewood Tephra, $3690 \pm$ 80 yr B.P. (Wk-1031A); Korito Tephra, $4150 \pm 100$ yr B.P.
(Wk-1033A); Tariki Tephra, $4590 \pm 100$ yr B.P. (Wk1034A); and Waipuku Tephra, $5260 \pm 90$ yr B.P. (Wk1035A). All of these ages are stratigraphically consistent and in close agreement with dates of equivalent unit: described elsewhere in Taranaki and Waikato (Table 1).

The radiocarbon date from beneath Stent tephra at Kaimata (T2) is considerably younger than the two other dates obtained from Onaero and Mangamingi, which are considered reliable and entirely consistent with the independent radiocarbon chronology established for the overlying Egmont-sourced Inglewood Tephra (c. $3.6 \mathrm{ka}$ ) and closely underlying Korito Tephra (c. 4.1 ka) (Fig. 2: Table 1). It is not clear why this Kaimata date should be significantly younger than the others, but it is possible it was subjected to contamination by younger carbon in the free-flowing open drain near the sampling site.

\section{Bay of Plenty}

Two cores (BP1 and BP2) were obtained from Papamo:a Bog using a D-section corer within c. $10 \mathrm{~m}$ of each other (Fig. 1B). In core BP1, Stent tephra was identified at $\mathrm{C}$. $3.4 \mathrm{~m}$ depth as a c. $20 \mathrm{~mm}$ thick, greyish-white medium ash layer (Fig. 3). Radiocarbon samples obtained immediately above and below the tephra yielded ages of $4060 \pm 80$ (Wk$1443 \mathrm{~A}$ ) and $3910 \pm 110 \mathrm{yr}$ B.P. (Wk-1444A), respectively. Whakaipo Tephra (as defined by Vucetich \& Pullar 1973) (also directly dated) was identified at c. $2 \mathrm{~m}$ depth, together with Hinemaiaia Tephra (as defined by Froggatt 1981c and Lowe 1986) at c. $4 \mathrm{~m}$ depth. Radiocarbon samples directly above Hinemaiaia Tephra, and $0.25 \mathrm{~m}$ below it, constrained its age (Fig. 3).

Core BP2 contains almost identical stratigraphy to BP1. Stent tephra was not obvious as a macroscopic layer but rather as a zone of dispersed glass at c. $3.2 \mathrm{~m}$ depth, which was radiocarbon dated at $3820 \pm 70 \mathrm{yr}$ B.P. (Wk-2151A). In a peaty swale immediately seaward of a large dune backing onto Papamoa bog (Fig. 1B, core BP3), Stent tephra was identified close to the base of the peat at c. $2 \mathrm{~m}$ depth and was dated at $4030 \pm 80 \mathrm{yr}$ B.P. (Wk-1565A). This age was confirmed by another date of $4140 \pm 80 \mathrm{yr}$ B.P. (Wk$1564 \mathrm{~A}$ ) from wood underlying the tephra from the peat/ sand interface (Fig. 3). Stent tephra is stratigraphically constrained by the presence of the geochemically distinctive Whakaipo Tephra (see Glass Composition section) above and, in core BP1, by Hinemaiaia Tephra below. Both these tephras were positively identified by a combination of radiocarbon chronology, ferromagnesian mineralogy, and glass composition (Wigley 1990; Lowe et al. 1992). Waimihia Tephra was not identified in the Papamoa cores and has yet to be found in western Bay of Plenty or the Waikato (Lowe 1988a).

\section{Ferromagnesian mineralogy and glass composition}

The ferromagnesian mineralogy of Stent tephra from two sites in Taranaki is dominated by orthopyroxene (c. $43 \%$ ) but contains a significant proportion of Egmont-sourced clinopyroxene (c. $30 \%$ ) and hornblende (c. $27 \%$ ) contaminants (Alloway 1989). At Papamoa, Stent tephra in core BP1 is also dominated by orthopyroxene (G. N. A. Wigley unpubl. data).

Glass shards of samples from two Taranaki localities (sections T2 and T3) were analysed for major elements using electron microprobe (EMP) analysis. Results show 

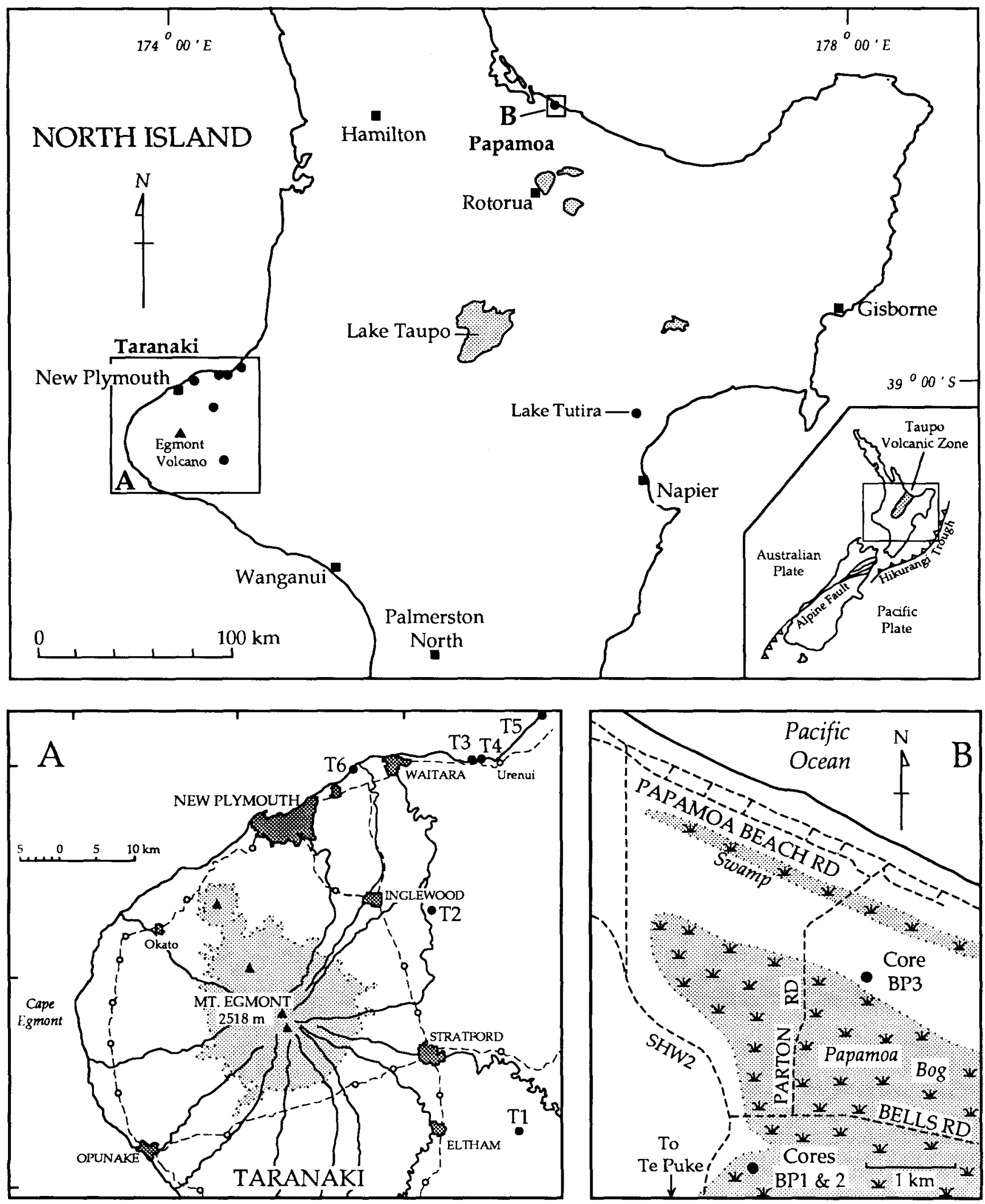

Fig. 1 Location map of Stent tephra sites in Taranaki (T1-T6) and Papamoa (BP1-BP3) in the North Island. A and B show detailed locations. 


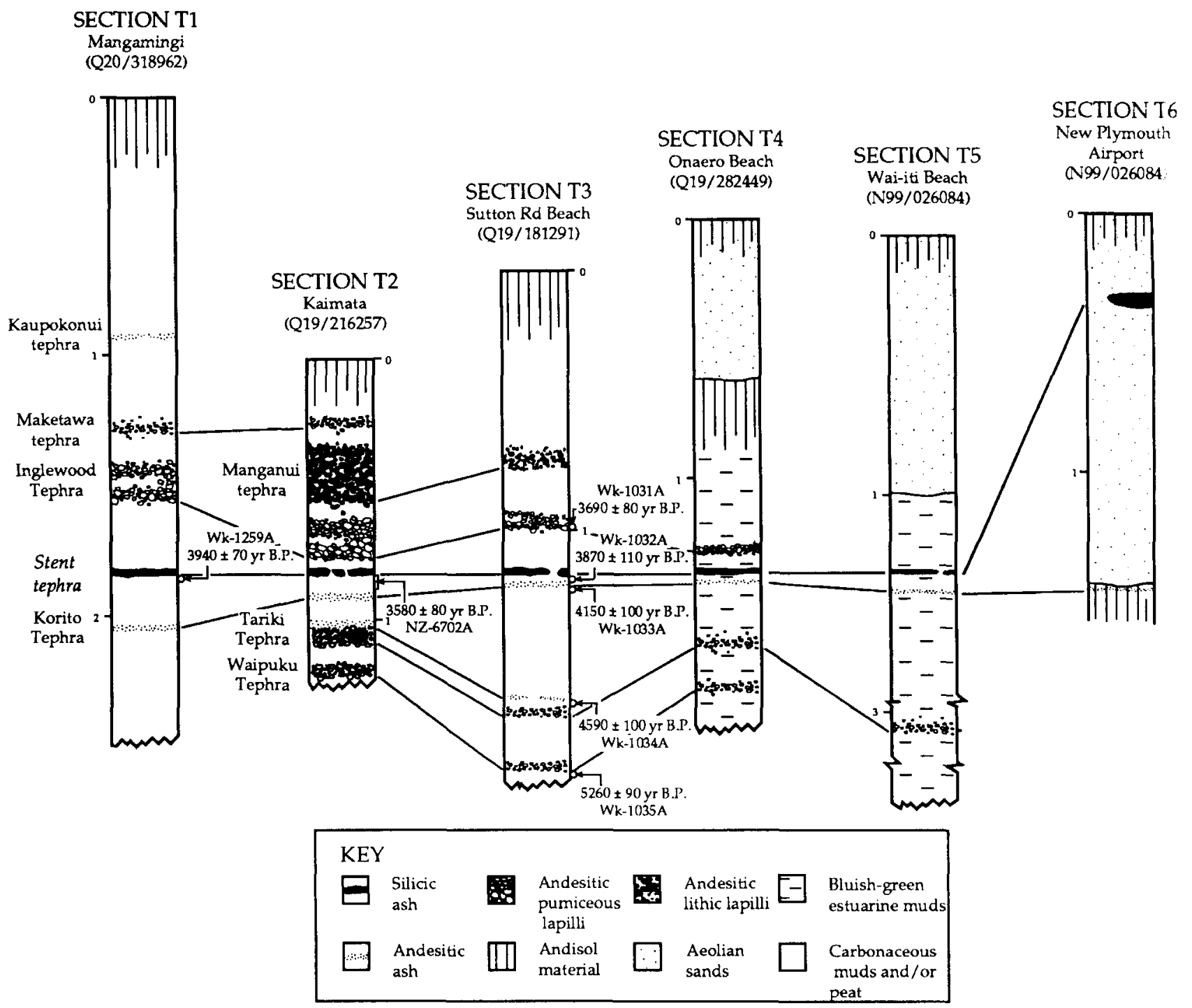

Fig. 2 Stratigraphic columns of tephras and radiocarbon dates from sections in Taranaki (see Fig. 1A); all ages are quoted as conventional ages based on the old half-life $(5568 \pm 30 \mathrm{yr})$. The uncorrelated silicic tephra is labelled Stent tephra.

Table 1 Radiocarbon dates of Egmont-sourced tephras relevant to the age of Stent tephra.

\begin{tabular}{|c|c|c|c|c|c|c|c|c|}
\hline $\begin{array}{l}\text { Tephra } \\
\text { formation }\end{array}$ & $\mathrm{Lab}^{\mathrm{a}}$ & $\begin{array}{c}{ }^{14} \mathrm{C} \\
\text { number }\end{array}$ & $\begin{array}{c}\text { Age }^{\mathrm{b}} \\
\text { (yr B.P.) }\end{array}$ & $\begin{array}{c}\text { Std } \\
\text { deviation } \\
\text { (SD) }\end{array}$ & $\begin{array}{c}\text { Sample } \\
\text { type }^{c}\end{array}$ & References ${ }^{d}$ & Collector & Comments \\
\hline \multirow[t]{2}{*}{ Manganui } & NZ & 3423 & 2890 & 100 & $\mathrm{P}$ & 2 & McGlone \& Neall & $\min$ \\
\hline & NZ & 3139 & 3320 & 60 & $\mathrm{P}$ & 2 & McGlone \& Neall & $\max$ \\
\hline \multirow[t]{4}{*}{ Inglewood } & $\mathrm{NZ}$ & 3353 & 3610 & 80 & W & 3 & Neall & $\min$ \\
\hline & Wk & 1031 & 3690 & 80 & $\mathbf{P}$ & 1 & Alloway & $\max$ \\
\hline & Wk & 539 & 3610 & 60 & $P$ & 4 & Lowe & $\min$ \\
\hline & Wk & 540 & 3750 & 70 & $P$ & 4 & Lowe & $\max$ \\
\hline Korito & Wk & 1033 & 4150 & 100 & $\mathbf{P}$ & 1 & Alloway & $\max$ \\
\hline Tariki & Wk & 1034 & 4590 & 100 & $\mathbf{P}$ & 1 & Alloway & $\min$ \\
\hline \multirow[t]{2}{*}{ Waipuku } & NZ & 3352 & 5000 & 90 & $\mathrm{~W}$ & 5 & Neall & $\min$ \\
\hline & Wk & 1035 & 5260 & 90 & $\mathbf{P}$ & 1 & Alloway & $\max$ \\
\hline
\end{tabular}

${ }^{a} \mathrm{NZ}=$ New Zealand Radiocarbon Dating Laboratory, Institute of Geological and Nuclear Sciences, Lower Hutt; Wk = University of Waikato Radiocarbon Dating Laboratory, Hamilton.

${ }^{b}$ All ages are quoted as conventional ages based on the old half-life ( $\left.5568 \pm 30 \mathrm{yr}\right)$.

cThe material dated is listed as $\mathrm{P}$, peat; $\mathrm{W}$, wood; $\mathrm{C}$, charcoal.

$\mathrm{d}$ The reference where first quoted or discussed in relation to the tephra is numbered; the key is below. For ages currently unpublished, the sources are also listed below: 1 Alloway (1989); 2 McGlone et al. (1988); 3 Neall (1979); 4 Lowe (1988a); 5 V. E. Neall - unpublished date.

'The comments listed as: $\min =$ sample overlies tephra formation; $\max =$ sample underlies tephra formation. 


\section{Core BP1}

Papamoa Bog (Kt16a) (U14/008793)
Core $\mathrm{BP} 2$

Papamoa Bog (Kt16b) (U14/008793)
Core BP3

Papamoa Bog (S3) (U14/ 009794)
Core 4

Lake Tutira, Hawkes Bay (V20/454146)

(from Eden et al. 1993 )

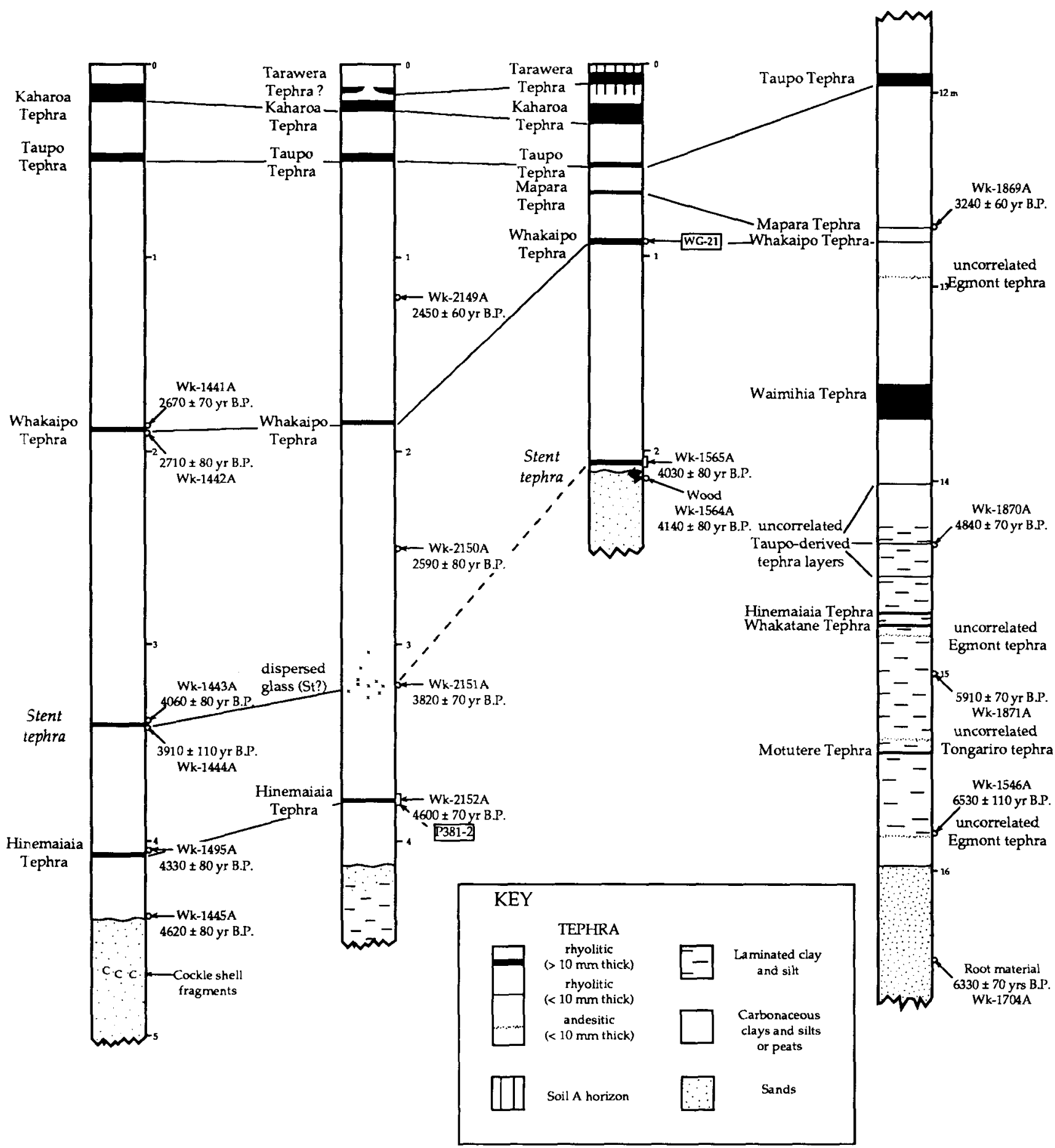

Fig. 3 Stratigraphic columns of tephras and radiocarbon dates from cores at Papamoa (see inset 1B) and Lake Tutira (see Fig. 1); all ages are quoted as conventional ages based on the old half-life $(5568 \pm 30 \mathrm{yr})$.

that each of the tephra layers sampled is homogeneous, as indicated by the generally low standard deviations (Table 2). The EMP analyses confirm that Stent tephra is silicic in composition, and cannot be differentiated from most other Taupo-derived tephras of Holocene age (exemplified by Hinemaiaia Tephra in Fig. 4). However, the analyses are distinct from the Whakaipo Tephra, pre-Holocene Tauposourced tephra (e.g., Aokautere Ash, Table 2) and Okatainasourced tephras (e.g., Rotoehu Tephra, Table 2) as illustrated in the $\mathrm{CaO}-\mathrm{FeO}-\mathrm{K}_{2} \mathrm{O}$ ternary diagram (Fig. 4) and in the literature (e.g., Lowe 1986; Stokes \& Lowe 1988).

Similarly, discriminant function analysis (DFA), based 


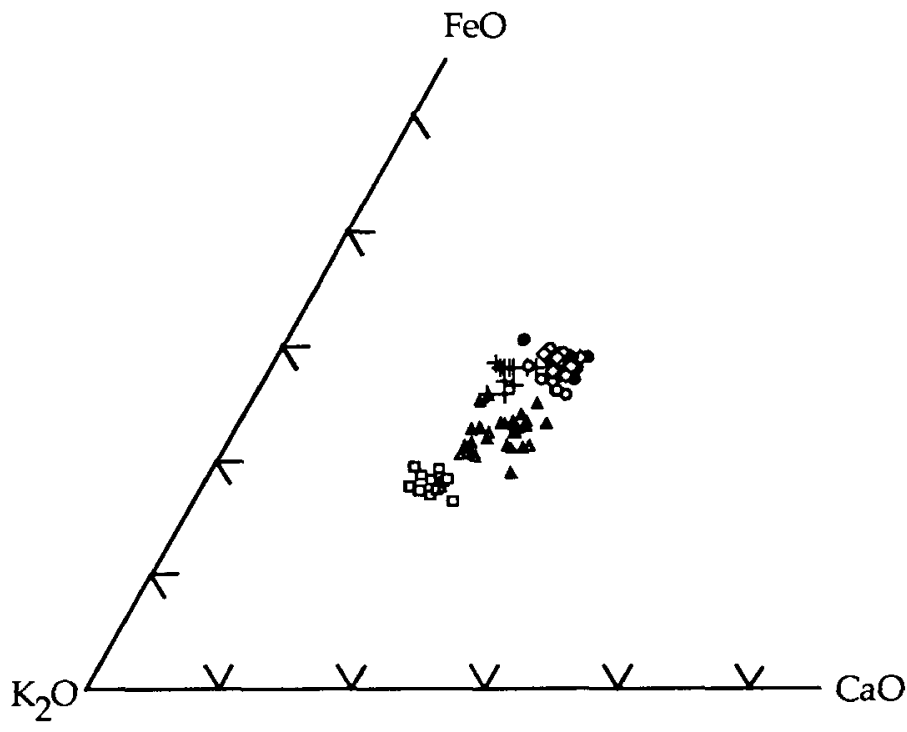

TARANAKI AND BAY OF PLENTY

\begin{tabular}{cc} 
& Stent tephra \\
- & Section T2 \\
& Section T3 \\
+ & Whakaipo Tephra \\
Core BP3 \\
Hinemaiaia Tephra \\
Core BP2 \\
A \\
Aokautere Ash \\
- Section 19 in Alloway (1989) \\
Section 30 in Alloway (1989) \\
Rotoehu Ash \\
\hline
\end{tabular}

Fig. $4 \mathrm{FeO}-\mathrm{CaO}-\mathrm{K}_{2} \mathrm{O}$ ternary plot showing the composition of Stent tephra compared with several other Taupo- and Okatainasourced tephra from Taranaki and western Bay of Plenty. Ticks on the diagram are at $10 \%$ intervals. on glass shard major element composition and using two canonical variates, could only distinguish Whakaipo Tephra. Analyses of the other Holocene Taupo tephras, including Stent tephra, were too similar to differentiate (see al $: 0$ Stokes \& Lowe 1988; Stokes et al. 1992).

\section{CHRONOLOGY OF STENT TEPHRA}

Radiocarbon dates relevant to Stent tephra from Taranaki and western Bay of Plenty are summarised in Table 3 and Fig. 5. The error-weighted mean age for a dataset of values is calculated by the formula

$\bar{t}=\frac{\sum_{i=1}^{n} \frac{t_{i}}{e_{i}^{2}}}{\sum_{i=1}^{n} \frac{1}{e_{i}^{2}}}$

where $e_{i}$ is the error associated with the $i$-th measurement $t_{i}$ (Ward \& Wilson 1978; Gupta \& Polach 1985). The error for the mean age is estimated by the formula

$$
\bar{e}=\frac{1}{\sqrt{\sum_{i=1}^{n} \frac{1}{e_{i}^{2}}}}
$$

The error-weighted mean ages and associated pooled errors obtained for the three datasets are: Waimihia Tephra $(n=14), 3232 \pm 20$ yr B.P.; Stent tephra $(n=8), 3919 \pm 29$ yr B.P.; Hinemaiaia Tephra $(n=14), 4525 \pm 20$ yr B.P.

It is evident that the means of these three datasets are statistically far apart. Plots of the individual data values shown in Fig. 5 reveal a discernable clustering around these distinct mean ages. This feature is also shown in the $99 \%$ confidence interval (CI) plots shown in Fig. 6. Since these CI plots do not overlap, we can conclude that there are significant differences between the mean ages. This

Table 2 Average major element composition of glass shards.

Table 2 Aranaki

(from Alloway 1989)

\begin{tabular}{|c|c|c|c|c|c|c|c|}
\hline & \multirow{2}{*}{\multicolumn{2}{|c|}{ Stent tephra }} & \multirow{2}{*}{\multicolumn{2}{|c|}{ Aokautere Ash }} & \multirow{3}{*}{$\begin{array}{c}\text { Rotoehu Ash } \\
\text { Section 30 } \\
\text { (RSES-50823) }\end{array}$} & \multicolumn{2}{|c|}{ \& P. C. Froggatt unpubl. data) } \\
\hline & & & & & & Whakaipo & Hinemaiaia \\
\hline & $\begin{array}{c}\text { Section T2 } \\
\text { (RSES-50823) }\end{array}$ & $\begin{array}{c}\text { Section T3 } \\
\text { (RSES-50824) }\end{array}$ & $\begin{array}{c}\text { Section } 19 \\
\text { (RSES-50819) }\end{array}$ & $\begin{array}{c}\text { Section 30 } \\
\text { (RSES-50821) }\end{array}$ & & $\begin{array}{l}\text { Tephra* } \\
\text { (WG-21) }\end{array}$ & $\begin{array}{c}\text { Tephra } \dagger \\
\text { (P381-2) }\end{array}$ \\
\hline $\mathrm{SiO}_{2}$ & $77.61 \pm 0.31$ & $77.46 \pm 0.35$ & $79.35 \pm 0.30$ & $79.00 \pm 0.66$ & $79.36 \pm 0.28$ & $77.76 \pm 0.22$ & $76.84 \pm 0.23$ \\
\hline $\mathrm{Al}_{2} \mathrm{O}_{3}$ & $12.51 \pm 0.17$ & $12.65 \pm 0.18$ & $12.40 \pm 0.12$ & $12.39 \pm 0.10$ & $12.38 \pm 0.09$ & $12.43 \pm 0.20$ & $12.86 \pm 0.10$ \\
\hline $\mathrm{FeO}$ & $1.64 \pm 0.09$ & $1.68 \pm 0.09$ & $1.19 \pm 0.11$ & $1.20 \pm 0.12$ & $0.88 \pm 0.06$ & $1.58 \pm 0.08$ & $1.75 \pm 0.05$ \\
\hline MgO & $0.14 \pm 0.03$ & $0.16 \pm 0.03$ & $0.12 \pm 0.01$ & $0.12 \pm 0.02$ & $0.14 \pm 0.01$ & $0.11 \pm 0.02$ & $0.17 \pm 0.02$ \\
\hline $\mathrm{CaO}$ & $1.26 \pm 0.10$ & $1.31 \pm 0.12$ & $1.07 \pm 0.09$ & $1.08 \pm 0.10$ & $0.83 \pm 0.06$ & $1.06 \pm 0.05$ & $1.26 \pm 0.30$ \\
\hline $\mathrm{TiO}_{2}$ & $0.20 \pm 0.06$ & $0.20 \pm 0.08$ & $0.12 \pm 0.03$ & $0.13 \pm 0.03$ & $0.14 \pm 0.03$ & $0.17 \pm 0.04$ & $0.21 \pm 0.03$ \\
\hline $\mathrm{Na}_{2} \mathrm{O}$ & $3.66 \pm 0.14$ & $3.58 \pm 0.48$ & $2.47 \pm 0.37$ & $2.81 \pm 0.46$ & $2.93 \pm 0.31$ & $3.60 \pm 0.25$ & $3.72 \pm 0.12$ \\
\hline $\mathrm{K}_{2} \mathrm{O}$ & $2.96 \pm 0.13$ & $2.96 \pm 0.07$ & $3.08 \pm 0.10$ & $3.10 \pm 0.28$ & $3.16 \pm 0.07$ & $3.15 \pm 0.16$ & $3.06 \pm 0.06$ \\
\hline $\mathrm{Cl}$ & - & - & $0.18 \pm 0.02$ & $0.18 \pm 0.03$ & $0.18 \pm 0.02$ & $0.14 \pm 0.03$ & $0.14 \pm 0.03$ \\
\hline $\mathrm{H}_{2} \mathrm{O}$ & $2.08 \pm 0.95$ & $3.16 \pm 1.43$ & $7.14 \pm 0.98$ & $6.45 \pm 0.94$ & $6.50 \pm 0.73$ & $3.40 \pm 1.75$ & $1.57 \pm 1.76$ \\
\hline$n$ & 11 & 10 & 15 & 15 & 11 & 11 & 10 \\
\hline
\end{tabular}

All major element determinations were made on a JEOL JXA-733 electron microprobe housed at Victoria University of Wellington. Analyses were determined using a beam current of $8 \mathrm{nA}$, beam diameter of 10 or $20 \mu \mathrm{m}$, and $3 \times 10 \mathrm{~s}$ peak counts (meaned). Values are in weight-percent oxide, recalculated to $100 \%$ on a fluid-free basis. $\mathrm{H}_{2} \mathrm{O}$ by difference from $100 \%$; total iron expressed as FeO; $n=$ number of analyses. The major element composition of internal glass standards KN-18, VG-99, and VG-568 were routinely analysed to check and correct for machine drift.

*Probably equivalent to unit- $V$ of Wilson (1993); tprobably equivalent to unit- $K$ of Wilson (1993). 


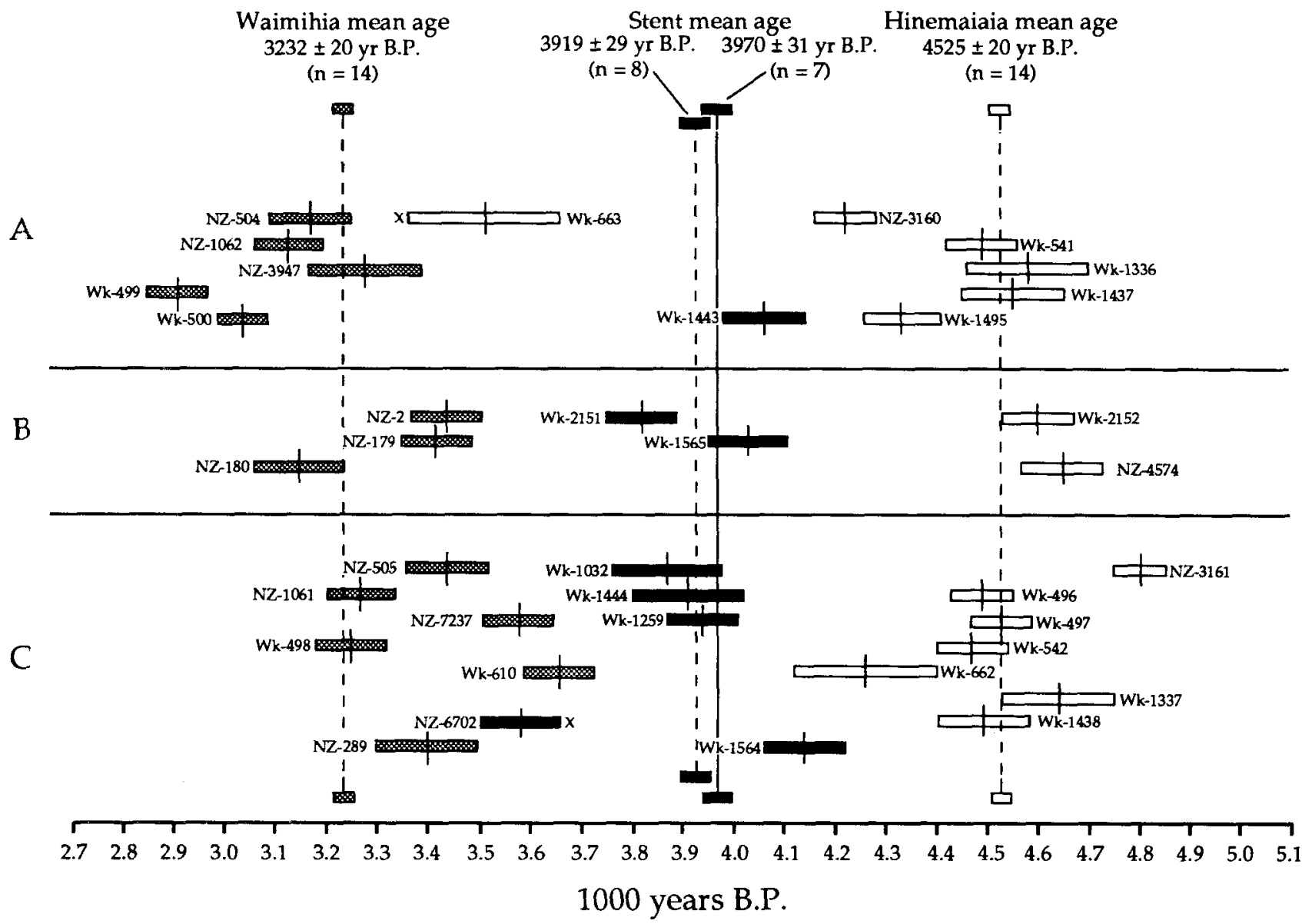

Fig. 5 Comparison of radiocarbon dates (old half-life) that apply to Waimihia Tephra, Stent tephra, and Hinemaiaia Tephra. For each age determination, one standard deviation is indicated. For each tephra, the dates are arranged according to sampling position: A, samples above tephra; B, samples within or straddling tephra; C, samples below tephra. Error-weighted mean age with pooled error, and the number of ages $(n)$ used in the mean age calculation for each tephra is also indicated; $\mathrm{x}$ denotes contaminated or spurious samples, which are excluded from weighted mean age calculations (Froggatt \& Lowe 1990).

Table 3 Radiocarbon dates directly relevant to Stent tephra.

\begin{tabular}{|c|c|c|c|c|c|c|c|c|}
\hline $\begin{array}{l}\text { Tephra } \\
\text { loc ality }\end{array}$ & $\mathbf{L a b}^{\mathrm{a}}$ & $\begin{array}{c}{ }^{14} \mathrm{C} \\
\text { number }\end{array}$ & $\underset{(\mathrm{yr} \text { B.P. })}{\text { Ageb }^{\mathrm{b}}}$ & $\begin{array}{l}\text { Std } \\
\text { deviation } \\
\text { (SD) }\end{array}$ & $\begin{array}{l}\text { Sample } \\
\text { type }^{\mathrm{c}}\end{array}$ & References $^{\mathrm{d}}$ & Collector & Comments \\
\hline \multicolumn{9}{|l|}{ Taranaki } \\
\hline $\mathrm{T} 1$ & Wk & 1259 & 3940 & 70 & $\mathrm{P}$ & 1 & Alloway & Immediately underlying \\
\hline $\mathrm{T}_{2}$ & $\mathrm{NZ}$ & 6702 & 3580 & 80 & $\mathbf{P}$ & 1 & Alloway & Bulk sample below tephra \\
\hline $\mathbf{T} 3$ & Wk & 1032 & 3870 & 110 & $\mathrm{P}$ & 1 & Alloway & Immediately underlying \\
\hline \multicolumn{9}{|c|}{ Bay of Plenty } \\
\hline $\mathrm{BP} 1$ & Wk & 1443 & 4060 & 80 & $\mathbf{P}$ & 2,3 & Lowe \& Wigley & Immediately overlying \\
\hline BP1 & Wk & 1444 & 3910 & 110 & $\mathbf{P}$ & 2,3 & Lowe \& Wigley & Immediately underlying \\
\hline $\mathrm{BP} 2$ & Wk & 2151 & 3820 & 70 & $\mathbf{P}$ & 4 & Lowe & Sample straddling tephra \\
\hline BP3 & Wk & 1565 & 4030 & 80 & $\mathbf{P}$ & 2,3 & Lowe \& Wigley & Sample straddling tephra \\
\hline $\mathrm{BP3}$ & Wk & 1564 & 4140 & 80 & W & 2,3 & Lowe \& Wigley & Below tephra \\
\hline \multirow{2}{*}{\multicolumn{3}{|c|}{$\begin{array}{l}\text { pooled mean age }(n=8) \\
\text { pooled mean age excluding } \\
\text { contaminated sample from } T 2(n=7\end{array}$}} & 3919 & 29 & & & & \\
\hline & & & $(3970)$ & (31) & & & & \\
\hline
\end{tabular}

${ }^{a} \mathrm{NZ}=$ New Zealand Radiocarbon Dating Laboratory, Institute of Geological and Nuclear Sciences, Lower Hutt;

Wk = University of Waikato Radiocarbon Dating Laboratory, Hamilton.

${ }^{b}$ All ages are quoted as conventional ages based on the old half-life $(5568 \pm 30 \mathrm{yr})$.

The material dated is listed as $P$, peat; $W$, wood; $C$, charcoal.

The reference where first quoted or discussed in relation to the tephra is numbered; the key is below: 1 Alloway (1989); 2 Wigley

(1990); 3 Lowe et al. (1992); 4 D. J. Lowe - unpublished date.

e Contaminated sample. 


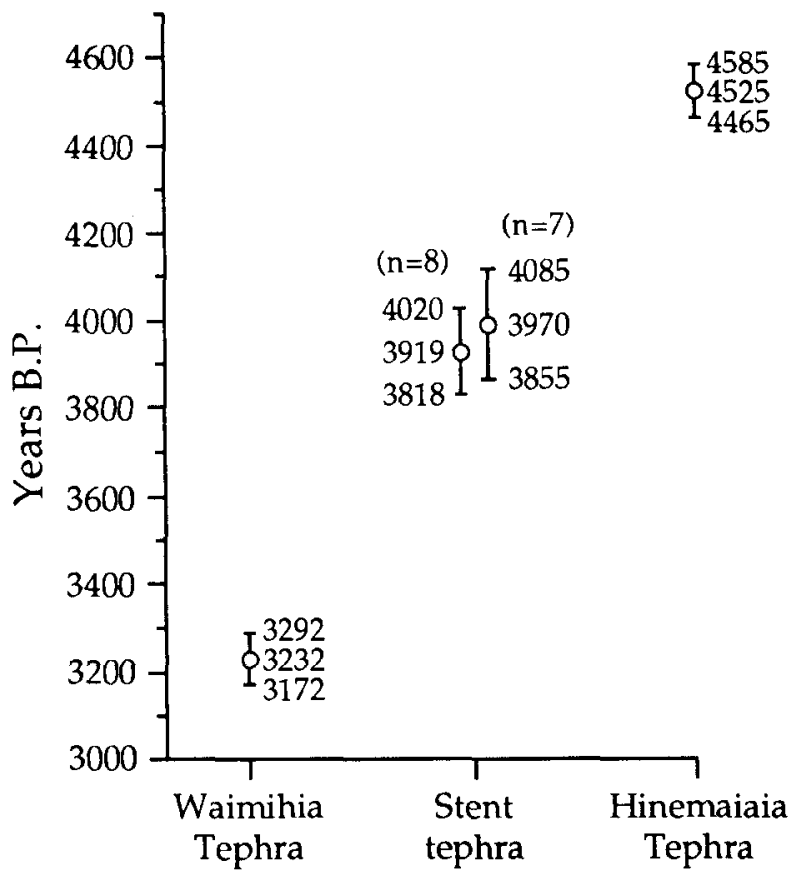

Fig. $699 \%$ confidence interval plots for Waimihia Tephra, Stent tephra ( $n=7$ excludes contaminated sample from section T2), and Hinemaiaia Tephra.

conclusion is corroborated by a weighted ANOVA test performed using SAS on all 35 data values. The $P$-value obtained was 0.0001 , which provides very strong evidence of significant differences between the mean ages. Separate $t$-tests for the difference between the mean age of the Waimihia Tephra and Stent tephra, $\mu_{U}-\mu_{W}$, and for the difference between the mean age of the Hinemaiaia Tephra and Stent tephra, $\mu_{H}-\mu_{U}$, were performed on the hypotheses:

$H_{0}: \mu_{U}=\mu_{W}, \quad H_{1}: \mu_{U}>\mu_{W}$

$H_{0}: \mu_{H}=\mu_{U}, \quad H_{1}: \mu_{H}>\mu_{U}$.

The test statistics, calculated using a pooled standard error by the formulae,

$$
t_{0}=\frac{\bar{t}_{1}-\bar{t}_{2}}{s_{p} \sqrt{\frac{1}{n_{1}}+\frac{1}{n_{2}}}}, s_{p}=\sqrt{\frac{\left(n_{1}-1\right) \bar{e}_{1}^{2}+\left(n_{2}-1\right) \bar{e}_{2}^{2}}{n_{1}+n_{2}-2}}
$$

gave values of 65.8 and 58.1 for $t_{0}$ in the two cases. From the corresponding extremely small $P$-values we conclude that Stent tephra is significantly older than the Waimihia Tephra and is significantly younger than the Hinemaiaia Tephra. There is thus strong evidence for the existence of a previously unrecognised silicic tephra lying stratigraphically between the c. $3.2 \mathrm{ka}$ Waimihia Tephra and the c. $4.5 \mathrm{ka}$ Hinemaiaia Tephra.

\section{DISCUSSION AND PROXIMAL-DISTAL CORRELATION}

The tephrostratigraphic and chronologic relationships of Stent tephra, unknown from previous studies in the Taupo area, are examined within organic deposits from two widely separated areas in western and northeastern North Island.
The existence of Stent tephra, previously reported from Taranaki, is confirmed by its unequivocal occurrence as a primary tephra deposit in two cores from Papamoa in west $m$ Bay of Plenty.

At Papamoa, Stent tephra occurs stratigraphically above the c. $4.5 \mathrm{ka}$ Hinemaiaia Tephra and below the c. $2.7 \mathrm{ka}$ Whakaipo Tephra (Waimihia Tephra is not found). Stent tephra at six sites in Taranaki is enveloped by Egmontsourced tephras dated at 3690 years (above) and 4150 years (immediately below). It seems very unlikely that Stent tephra could represent the reworked product of Hinemaiaia Tephra-such redeposition would be required to have occurred in diverse depositional environments broadly within the same time interval and at widely separated North Island localities. Similarly, it is unlikely that all radiocarbon dates associated with Stent tephra as well as other andesitic tephras dated at various sites are spuriously young.

Stent tephra has an orthopyroxene-dominated ferromagnesian mineralogy and glass chemistry characteristic of a Taupo Volcanic Centre source. The demonstrated occurrence of Stent tephra in Taranaki, $160 \mathrm{~km}$ upwind from the postulated source area, together with its occurrence in western Bay of Plenty, indicates that it apparently represents the product of a moderately large, possibly westward-directed plinian eruption (Fig. 7). The eight radiocarbon dates obtained on peat or gyttja associated $w$ ith Stent tephra provide an eruptive age of $3919 \pm 29$ yr B.P. However, if the contaminated radiocarbon sample from section T2 is excluded from weighted mean calculations, a more reliable age estimate is found to be $3970 \pm 31 \mathrm{yr}$ B.P. (Table 3; Fig. 5).

\section{Proximal correlation}

Extensive previous study in the Taupo area before 1993 had not identified a near-source equivalent tephra deposit intervening between Waimihia and Hinemaiaia Tephras. However, Wilson (1993) has now constructed a new detailed stratigraphy and identified 28 eruptions postdating the $\mathrm{c}$. 22.6 ka Kawakawa (Oruanui) eruption. Hinemaiaia Tephra, previously defined by Froggatt (1981c), was reinterpreted by Wilson to represent 10 discrete units erupted between 3950 and $5200 \mathrm{yr}$ B.P., these units being separated on the basis of intervening weak paleosols and/or erosion breaks. These newly identified units have been mapped, but correlation of individual units from source was difficult because many rarely exceed $0.20 \mathrm{~m}$ thickness and they rapidly merge together. Of the 10 eruptive units that comprise "Hinemaiaia Tephra", only one (unit- $K$ ) is considered to represent an eruption powerful enough $\left(\geq 0.35 \mathrm{~km}^{3}\right)$ to be widely represented throughout the entire Taupo area (Wilson 1993) (Fig. 7). This unit is correlated with the c. $4.5 \mathrm{ka}$ "Hinemaiaia Tephra" bed identified from previous studies in distal localities (Kohn et al. 1981; Lowe \& Hogg 1986; Lowe 1986) and in this paper. However, another two unitsunit- $Q$ erupted at c. $4.0 \mathrm{ka}$ and unit- $N$ at c. $4.2 \mathrm{ka}-$ are considered moderately powerful eruptions $\left(\geq 0.15 \mathrm{~km}^{3}\right)$ by "Hinemaiaia" standards (Wilson 1993) and therefore have the most likely potential to be widely dispersed over the central North Island. Other proximal units broadly within the same age range are apparently too small in volume $\left(\leq 0.05 \mathrm{~km}^{3}\right)$ to be represented at distal localities.

The age of unit- $Q$, estimated by Wilson (1993) at c. 4050 yr B.P., is in good agreement with the age we have 


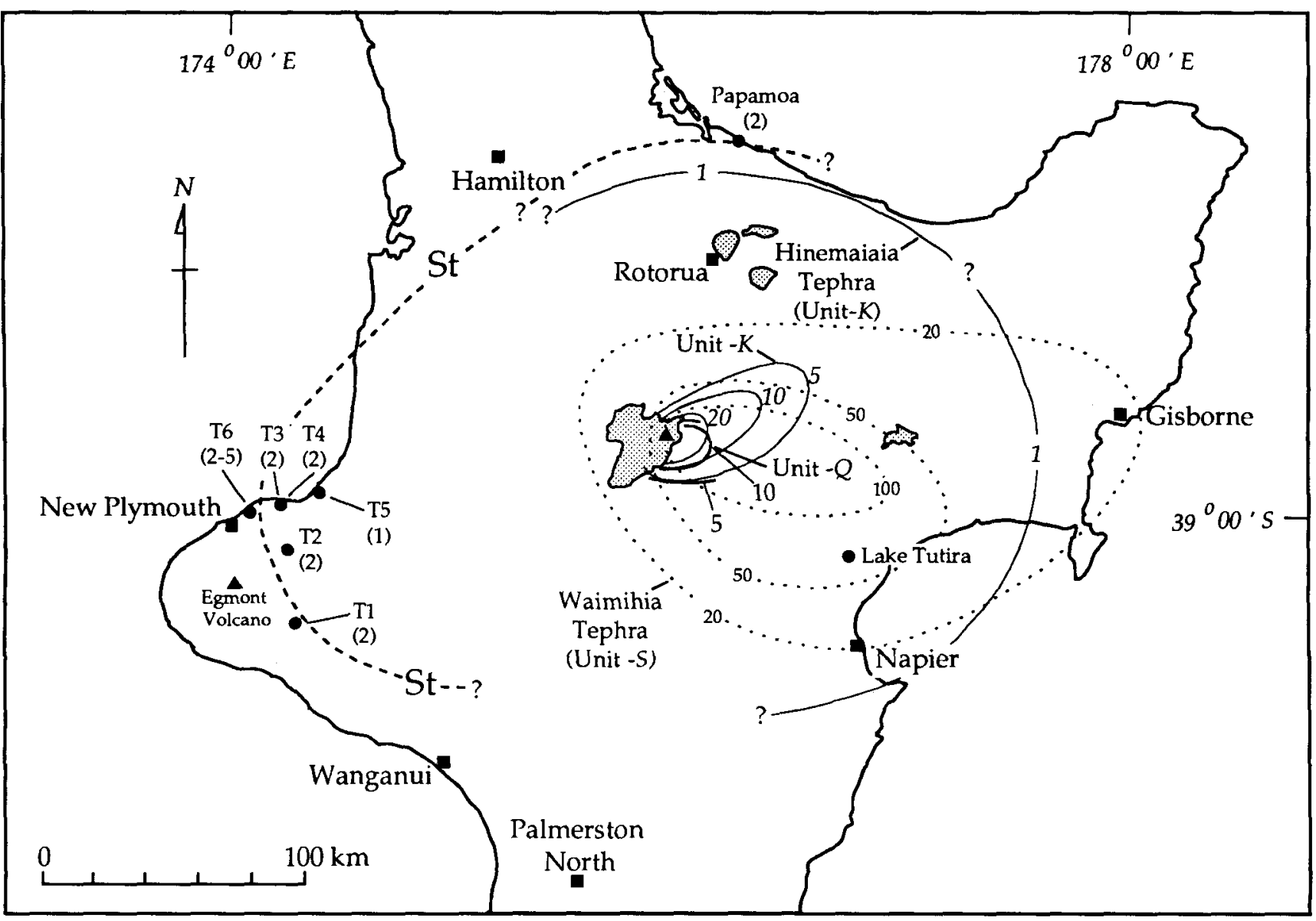

Fig. 7 Possible distal distribution of Stent tephra. The dashed line (St) is a tentative c. $2 \mathrm{~cm}$ isopach of Stent tephra based on its estimated thickness at the sites indicated. The isopachs (in centimetres) for "Hinemaiaia Tephra" (equivalent to unit- $K$ of Wilson 1993) - thin solid line (from Lowe 1986 and Wilson 1993); unit- $Q$ - heavy solid line (from Wilson 1993); Waimihia Tephra (unit- $S$ of Wilson 1993) - dotted line (from Vucetich \& Pullar 1973) are included for comparison. The approximate source location of unit- $K$ and unit- $Q$ in the vicinity of Lake Taupo is indicated by a triangle (from Wilson 1993).

determined for Stent tephra from seven samples $(3970 \pm 31$ yr B.P.). Though slightly older than Stent tephra, the age of unit- $Q$ is based on a maximum radiocarbon date ( $\mathrm{Wk}-$ 1839) of $4130 \pm 70 \mathrm{yr}$ B.P. obtained from charcoal within the directly underlying paleosol. Tentative correlation is therefore suggested between the distal Stent tephra and proximal unit- $Q$. However, until unequivocal correlation is established, it is appropriate to continue using the name Stent tephra at its distal localities (following the Wellman 1962 precedence).

\section{Lake Tutira}

At present, it is unclear whether Stent tephra correlates with any of the uncorrelated Taupo-sourced tephra layers recognised from Lake Tutira, Hawke's Bay (Eden et al. 1993) (Fig. 3, core 4). Ages for these layers were not directly determined (there is an "old carbon" effect evident in the lake sediments), but instead were estimated by assuming uniform rates of sedimentation between the c. $3.2 \mathrm{ka}$ Waimihia Tephra (unit- $S$ of Wilson 1993) (above) and the 4.5 ka Hinemaiaia Tephra (unit- $K$ of Wilson 1993) (below). Two of these layers (c. 3700 and c. $4100 \mathrm{yr}$ B.P.) were considered by Eden et al. (1993) to be reworked units due to rounding of their mineral components and the presence of contaminant grains, but the third and lowermost (c. 4300 yr B.P.) exhibited none of these features and was thought to represent a primary airfall deposit. However, it is now possible that these layers represent distal equivalents of post- $K$ "Hinemaiaia" units (Wilson 1993), some of which may have been sufficiently large to be distributed downwind from source and preserved at Lake Tutira (Fig. 7). In the absence of more precise age and compositional data for these layers, correlation to Stent tephra or individual post- $K$ "Hinemaiaia" units of Wilson (1993) remains uncertain, but tentative correlations (from oldest to youngest) with units $-N,-Q$, and $-R$ are suggested.

\section{ACKNOWLEDGMENTS}

This research was part funded by the Department of Soil Science at Massey University (B. V. Alloway), the University of Waikato Research Committee (D. J. Lowe), and Foundation for Research, Science and Technology (D. N. Eden). We thank Glenn Wigley, Jim Dahm, and Yoshitaka Nagatomo for help with the coring at Papamoa. We also thank Colin Vucetich, Vince Neall, and Colin Wilson for reading an early version of the manuscript and for making several helpful comments. The final manuscript benefited from reviews by Jim Begét, University of Alaska, and an anonymous reviewer. 


\section{REFERENCES}

Alloway, B. V. 1989: Late Quaternary cover bed stratigraphy and tephrochronology of north-eastern and central Taranaki, New Zealand. Unpublished Ph.D. thesis, lodged in the Library, Massey University, Palmerston North.

Alloway, B. V.; Stewart, R. B.; Neall, V. E.; Vucetich, C. G. 1992: Climate of the Last Glaciation based on aerosolic quartz influx in an andesitic terrain. Quaternary research 38: $170-179$.

Baumgart, I. L. 1954: Some ash showers of the central North Island. New Zealand journal of science and technology B35: 456-467.

Baumgart, I. L.; Healy, J. 1956: Recent volcanicity at Taupo, New Zealand. Proceedings of the 8th Pacific Science Congress 2: 113-125.

Eden, D. N.; Froggatt, P. C.; Trustrum, N. A.; Page, M. J. 1993: A multiple-source Holocene tephra sequence from Lake Tutira, Hawke's Bay, New Zealand. New Zealand journal of geology and geophysics 36: 233-242.

Froggatt, P. C. $1981 \mathrm{a}$ : Review of Holocene eruptions from Taupo. In: Howorth, R. et al. ed. Proceedings of tephra workshop. Geology Department Victoria University of Wellington publication 20: 21-28.

Froggatt, P. C. 1981b: Karapiti Tephra Formation: a 10000 years B.P. tephra from Taupo. New Zealand journal of geology and geophysics 24: 95-98.

Froggatt, P. C. 1981c: Motutere Tephra Formation and redefinition of Hinemaiaia Tephra Formation, Taupo Volcanic Centre, New Zealand. New Zealand journal of geology and geophysics 24: 99-105.

Froggatt, P. C. 1981d: Stratigraphy and nature of Taupo Pumice Formation. New Zealand journal of geology and geophysics 24: 231-248.

Froggatt, P. C. 1982: A study of some aspects of the volcanic history of the Lake Taupo area, North Island, New Zealand. Unpublished Ph.D. thesis, lodged in the Library, Victoria University of Wellington, Wellington.

Froggatt, P. C.; Lowe, D. J. 1990: A review of late Quaternary silicic and some other tephra formations from New Zealand: their stratigraphy, nomenclature, distribution, volume, and age. New Zealand journal of geology and geophysics 33: 89-109.

Froggatt, P. C.; Rogers, G. M. 1990: Tephrostratigraphy of high altitude peat-bogs along the axial ranges, North Island, New Zealand. New Zealand journal of geology and geophysics 33: 111-124.

Gupta, S. K.; Polach, H. A. 1985: Radiocarbon dating procedures at ANU. Handbook, Radiocarbon Laboratory. Canberra, Australian National University.

Healy, J. 1964: Dating of the younger volcanic eruptions of the Taupo region. Part 1. New Zealand Geological Survey bulletin 73: 7-39.

Hogg, A. G.; McCraw, J. D. 1983: Late Quaternary tephras of Coromandel Peninsula, North Island, New Zealand: a mixed peralkaline and calcalkaline tephra sequence. New Zealand journal of geology and geophysics 26: 163-187.

Kohn, B. P.; Neall, V. E.; Stewart, R. B. 1981: Holocene tephrostratigraphy revisited at Tiniroto, North Island, New Zealand. In: Howorth, R, et al. ed. Proceedings of tephra workshop. Geology Department Victoria University of Wellington publication 20: 60-66.
Lowe, D. J. 1986: Revision of the age and stratigraptic relationships of Hinemaiaia Tephra and Whakatane A ih, North Island, New Zealand, using distal occurrence in organic deposits. New Zealand journal of geology ind geophysics 29: 61-73.

Lowe, D. J. 1988a: Stratigraphy, age, composition and correla of late Quaternary tephras interbedded with organic sediments in Waikato lakes, North Island, New Zealiand. New Zealand journal of geology and geophysics i: 125-165.

Lowe, D. J. 1988b: Late Quaternary volcanism in New Zealand towards an integrated record using distal airfall tephras in lakes and bogs. Journal of Quaternary science 3: $111-120$

Lowe, D. J.; Hogg, A. G. 1986: Tephrostratigraphy and chronology of the Kaipo Lagoon, an 11,500 year-old montane peat bog in Urewera National Park, New Zealand. Journal of the Royal Society of New Zealand 16: 25-41.

Lowe, D. J.; Hogg, A. G.; Green, J. D.; Boubée, J. A. T. 1980: Stratigraphy and chronology of late Quaternary tephras in Lake Maratoto, Hamilton, New Zealand. New Zealand journal of geology and geophysics 28: 481-485.

Lowe, D. J.; Wigley, G. N. A.; Dahm, J.; Nagatomo, Y. 1992: Late Quaternary tephrostratigraphy and Holocene dune development in the Papmoa-Te Puke area, Bay of Plenty. In: Rijske, W. J. comp. Field notes for the field days for the 1992 Conference of the New Zealand Society of soil Science, Rotorua. Pp. 36-41.

McGlone, M. S.; Neall, V. E.; Clarkson, B. D. 1988: The effe $\iota t$ of recent volcanic events and climatic changes on the vegetation of Mt Egmont (Mt Taranaki), New Zealinnd. New Zealand journal of botany 26: 123-144.

Neall, V. E. 1972: Tephrochronology and tephrostratigraphy of western Taranaki (N108-109), New Zealand. New Zealand journal of geology and geophysics 15: 507-557.

Neall, V. E. 1979: Sheets P19, P20, and P21-New Plymouth, Egmont and Manaia. Geological map of New Zealand 1:50 000. 3 maps and notes. 36 p. Wellington, Department of Scientific and Industrial Research.

Neall, V. E.; Alloway, B. V. 1986: Quaternary volcaniclastics and volcanic hazards of Taranaki. New Zealand Geological Survey record 12: 101-137.

Pillans, B. J.; Wright, I. 1992: Late Quaternary tephrostratigraphy from the southern Havre Trough - Bay of Plenty, northeast New Zealand. New Zealand journal of geology and geophysics 35: 129-143.

Stewart, R. B.; Neall, V. E.; Pollock, J. A.; Syers, J. K. 1977: Parent material stratigraphy of an Egmont loam profile, Taranaki, New Zealand. Australian journal of soil research 15: $177-190$.

Stokes, S.; Lowe, D. J. 1988: Discriminant function analysis of late Quaternary tephras from five volcanoes in New Zealand using glass shard major element chemistry. Quaternary research 30: 270-283.

Stokes, S.; Lowe, D. J.; Froggatt, P. C. 1992: Discriminant function analysis and correlation of late Quaternary rhyolitic tephra deposits from Taupo and Okataina volcanoes. New Zealand, using glass shard major element composition. Quaternary international 13/14: 103-117.

Topping, W. W.; Kohn, B. P. 1973: Rhyolitic tephra marker beds in the Tongariro area, North Island, New Zealand. New Zealand journal of geology and geophysics 16: 375--395.

Vucetich, C. G.; Howorth, R. 1976a: Proposed definition of the Kawakawa Tephra, the c. 20000 yr B.P. marker horizon in the New Zealand region. New Zealand journal of geology and geophysics 19: 43-50. 
Vucetich, C. G.; Pullar, W. A. 1969: Stratigraphy and chronology of late Pleistocene volcanic ash beds in central North Island, New Zealand. New Zealand journal of geology and geophysics 12: 784-837.

Vucetich, C. G.; Pullar, W. A. 1973: Holocene tephra formations erupted in the Taupo area and interbedded tephras from other sources. New Zealand journal of geology and geophysics 16: 745-780.

Walker, G. P. L. 1980: The Taupo plinian pumice: product of the most powerful known (ultraplinian) eruption? Journal of volcanology and geothermal research 8: 59-94.

Wilker, G. P. L. 1981a: The Waimihia and Hatepe plinian deposits from the rhyolitic Taupo Volcanic Centre. New Zealand journal of geology and geophysics 24: 305-324.

Walker, G. P. L. 1981b: Characteristics of two phreatoplinian ashes, and their water flushed origin. Journal of volcanology and geothermal research 9: 395-407.

Ward, G. K.; Wilson, S. R. 1978: Procedures for comparing and combining radiocarbon age determinations: a critique. Archaeometry 20: 19-31.
Wellman, H. W. 1962: Holocene of the North Island of New Zealand: a coastal reconnaissance. Transactions of the Royal Society of New Zealand 1: 29-99.

Wigley, G. N. A. 1990: Holocene tephrochronology and evolution of the Te Puke lowlands, Bay of Plenty, New Zealand. Unpublished M.Sc. thesis, lodged in the Library, University of Waikato, Hamilton

Wilson, C. J. N. 1993: Stratigraphy, chronology, styles and dynamics of late Quaternary eruptions from Taupo volcano, New Zealand. Philisophical transactions of the Royal Society, London A 343: 205-306.

Wilson, C. J. N.; Ambraseys, N. N.; Bradley, J.; Walker, G. P. L. 1980: A new date for the Taupo eruption, New Zealand. Nature 288: 252-253.

Wilson, C. J. N.; Rogan, A. M.; Smith, I. E. M.; Northey, D. J.; Nairn, I. A.; Houghton, B. F. 1984: Caldera volcanoes of the Taupo Volcanic Zone, New Zealand. Journal of geophysical research 89: 8463-8484.

Wilson, C. J. N.; Houghton, B. F.; Lloyd, E. F. 1986: Volcanic history and evolution of the Maroa-Taupo area, central North Island. In: Smith, I. E. M. ed. Late Cenozoic volcanism in New Zealand. Royal Society of New Zealand bulletin 23: 194-223. 